\title{
BRPKM
}

Buletin Riset Psikologi dan Kesehatan Mental

http://e-journal.unair.ac.id/index.php/BRPKM

e-ISSN: 2776-1851

ARTIKEL PENELITIAN

\section{Pengaruh Kepuasan dan Stres Kerja terhadap Turnover Intention pada Pengurangan Gaji Karyawan Saat Pandemi}

\author{
Rizky Nanda Pratama Ibrahim \& Fendy Suhariadi* \\ Fakultas Psikologi Universitas Airlangga
}

\begin{abstract}
ABSTRAK
Penelitian ini bertujuan untuk mengetahui ada tidaknya pengaruh antara kepuasan kerja dan stres kerja terhadap turnover intention pada karyawan yang mengalami penurunan gaji atau tunjangan pada masa pandemi. Metode penelitian yang digunakan dalam penelitian ini merupakan kuantitatif yang bertujuan untuk menguji suatu teori atau hipotesis guna memperkuat atau bahkan menolak teori atau hipotesis hasil penelitian yang sudah ada sebelumnya. Pengambilan sample menggunakan Teknik survey google form dan memperoleh responden sebanyak 70 orang. Skala turnover intention yang dikembangkan dari Mobley, skala kepuasan kerja oleh Wexley dan Yukl, serta stres kerja oleh Beehr dan Franz. Hasil dari penelitian ini menunjukan bahwa uji regresi berganda antara kepuasan kerja dan stres kerja memilki pengaruh sebesar 6,3\% namun variabel stres kerja tidak berpengaruh signifikan dan kepuasan kerja berpengaruh signifikan. Namun uji regresi sederhana menunjukan tidak ada pengaruh antara kedua varibel tersebut pada turnover intention.
\end{abstract}

Kata kunci: kepuasan kerja, stres kerja, turnover intention

\begin{abstract}
This study aims to determine whether there is an influence between job satisfaction and work stress on turnover intention in employees who experience a decrease in salary or benefits during the pandemic. The research method used in this research is quantitative which aims to test a theory or hypothesis in order to strengthen or even reject the theory or hypothesis of pre-existing research results. Sampling using google form survey technique and obtained as many as 70 respondents. Turnover intention scale developed from Mobley, the job satisfaction scale by Wexley and Yukl, and work stress by Beehr and Franz. This study indicates that the multiple regression test between job satisfaction and job stress has effect of $6.3 \%$ but the work stress variable has no significant effect and job satisfaction has a significant effect. However, the simple regression test showed that there was no effect between the two variables on turnover intention.
\end{abstract}

Keywords: job satisfaction, job stress, turnover intention

Buletin Penelitian Psikologi dan Kesehatan Mental (BRPKM), 2021, Vol. 1(2), 1388-1396

*Alamat kopartisipansi: Fakultas Psikologi Universitas Airlangga, Kampus B Universitas Airlangga Jalan Airlangga 4-6 Surabaya 60286. Surel: fendy.suhariadi@psikologi.unair.ac.id 
sehingga penggunaan, distribusi, reproduksi dalam media apapun atas artikel ini tidak dibatasi, selama sumber aslinya disitir dengan baik.

\section{PENDAHULUAN}

Virus corona dalam kondisi saat ini bukanlah sebuah situasi yang dapat diabaikan begitu saja. Mulai dari segi gejalanya, orang normal sering mengira bahwa itu sebatas pada flu biasa, Tetapi dari analisa medis virus corona ini cukup menimbulkan efek yang berbahaya. Penyebaran dan perkembangan virus ini di tahun 2020 menjadi sangat penting karena menyebar ke seluruh dunia, dan semua negara termasuk Indonesia sudah merasakan dampaknya (Sumarni, 2020)(Sumarni \& Bengkulu, 2020). Penularan ini biasanya terjadi melalui kontak droplet dengan virus, dan virus kemudian dapat masuk ke dalam mukosa yang terpapar. Analisis mencoba mengukur tingkat penularan berdasarkan masa inkubasi, gejala, dan durasi gejala pasien terisolasi. Hasil analisis menunjukkan bahwa satu pasien menginfeksi tiga orang di sekitar, tetapi kemungkinan penularan selama masa inkubasi menyebabkan kontak pasienke-orang yang lebih lama, yang menempatkan satu pasien pada risiko infeksi yang lebih besar.

Dampak pandemi juga mengharuskan perkantoran, pabrik, toko ritel, dan usaha kecil untuk mengubah model bisnisnya. Industri besar seperti mobil atau perusahaan manufaktur pakaian jadi yang mengandalkan rantai pasokan global untuk memproduksi bahan mentah mengalami gangguan parah. Beberapa pabrik yang masih berproduksi juga harus menerapkan aturan jarak antar pekerja dan membaginya menjadi shift dengan pekerja lebih sedikit per shift (Yapanto, 2020). Akibatnya, salah satu dampak yang terjadi pada masa wabah tersebut menyebabkan banyak pekerja yang diberhentikan sementara atau bahkan diberhentikan, dan manajemen banyak perusahaan besar terkena imbas berupa pemotongan gaji atau pengurangan tunjangan (Yapanto, 2020).

Ketidakpuasan ataupun kepuasan gaji yang diterima oleh karyawan merupakan ketidakcocokan antara apa yang diterima dan apa yang dikerjakan oleh seseorang. Kepuasan gaji dapat memprediksi turnover dan absensi karyawan. Banyak penelitian memberikan kesimpulan bahwa adanya hubungan kepuasan gaji dengan turnover intention dan hasilnya adalah negatif (Andini, 2006).

Dalam penelitian Tillama \& Wirawan (2021) mengatakan bahwa turnover intention karyawan yang diteliti tidak memiliki hubungan dengan variable yang ditelitinya, menurutnya hal ini dikarenakan faktor pandemi yang membuat para pekerja berpikir dua kali untuk turnover intention. Perusahaan yang menjadi tempat penelitian ini pada tahun 2019 memiliki tingkat turnover tahunan sebesar 28\% sedangkan pada masa pandemi ini sedikit sekali karyawan yang melakukan turnover.

Menurut Andini (2006), Jika turnover pada akhirnya mengarah kepada kenyataan yang dihadapi oleh organisasi yaitu berkurangnya karyawan atau jumlah karyawan yang meninggalkan organisasi atau perusahaan pada periode tertentu, sedangkan keinginan karyawan untuk berpindah (turnover intention) mengacu pada hasil evaluasi individu tentang bagimana kelanjutan hubungan dengan perusahaan yang belum dapat diwujudkan dala tindakan yang pasti apakah individu tersebut akan meninggalkan perusahaan atau tidak. Turnover intention dapat berupa pengunduran diri, perpindahan keluar unit organisasi, dan pemberhentian atau kematian karyawan.

Dalam penelitian Hidayat (2018) menunjukkan bahwa intention to leave atau turnover intention mengacu pada niat karyawan untuk mencari alternatif pekerjaan lain dan belum terwujud dalam perilaku. Turnover karyawan yang tinggi, secara lambat tetapi pasti, akan menyebabkan perusahaan mengalami kemunduran kinerja. Turnover merupakan kriteria yang cukup baik untuk mengukur stabilitas perusahaan dan dapat mencerminkan kinerja dari perusahaan. 
Keinginan karyawan untuk pindah kerja (turnover intention) sendiri mengacu kepada hasil evaluasi individu mengenai kelanjutan hubungannya dengan sebuah perusahaan yang belum diwujudkan dalam tindakan nyata meninggalkan perusahaan tersebut (Sutanto \& Gunawan, 2013). Oleh karena itu, upaya untuk mengendalikan dan menurunkan employee turnover, dapat dimulai dengan menghilangkan turnover intention karyawan (Pareke, 2004). Selain masalah ketidakpuasan dalam pekerjaan, adanya penurunan komitmen organisasional akan memicu terjadinya perpindahan kerja.

Ketidakpuasan kerja telah sering diidentifikasikan sebagai suatu alasan penting yang dapat menyebabkan individu meninggalkan pekerjaannya (Hulin dkk., 1985). Selain itu, ketidakpuasan kerja seorang karyawan juga menimbulkan berbagai masalah, seperti meningkatnya tingkat absen karyawan, perilaku kerja pasif serta dapat merusak atau mengganggu kinerja pekerja lain (DeMicco \& Reid, 1988).

Pekerja yang cenderung memiliki kepuasan kerja yang rendah akan memiliki turnover yang tinggi, tingkat absensi yang tinggi, kelambanan dalam bekerja, keluhan atau bahkan mogok kerja. Mathis \& Jackson (2001) mengidentifikasi bahwa masuk-keluar (turnover) tenaga kerja berhubungan dengan ketidakpuasan kerja. Penelitian Roza (2020) yang meneliti tentang perbedaan kepuasan kerja karyawan sebelum dan semasa pandemi covid-19 menemukan bahwa karyawan dinilai lebih rendah daripada sebelum masa pandemi covid-19 terjadi, dari data yang ditemukan diantara beberapa jenis pekerjaan yaitu PNS, BUMN, BUMD, dan karyawan swasta hanya pegawai PNS yang merasa puas saat masa pandemi. Namun, jenis pekerjaan lainnya memiliki kepuasan kerja yang rendah saat masa pandemi, dapat dikatakan bahwa masa pandemi ini membuat kepuasan kerja menurun.

Penelitian Siyamto \& Saputra (2021) mengakatan pandemi yang sedang berlangsung mengakibatkan pemotongan gaji, pembatasan pada pergerakan, baik transportasi maupun aktivitas. Hal ini menyebabkan karyawan pada umumnya akan mencari jalan keluar dengan harapan untuk mendapatkan keadaan yang lebih baik (turnover), tindakan turnover yang dilakukan karyawan ini akan berimbas pada perusahaan salah satunya adalah cost (biaya) perusahaan apabila karyawan yang keluar merupakan karyawan yang berkompetensi dan dibutuhkan oleh perusahaan (Rokhmah \& Riani, 2005). Handoko (1998) menyatakan bahwa salah satu tujuan-tujuan administrasi kompensasi dalam hal ini penggajian adalah untuk mempertahankan karyawan yang ada, bila kompensasi tidak kompetitif dan tidak memenuhi prinsip keadilan, maka akan berimplikasi banyaknya karyawan yang baik akan keluar. Selain kepuasan kerja faktor lain yang mempengaruhi turnover karyawan yaitu stres kerja, masa krisis atau masa pandemi ini menyebabkan stres di seluruh jajaran masyarakat. Ketakutan dan kecemasan tentang pandemi covid-19 ini, ditambah faktor lainnya dapat mempengaruhi stres kerja. Stres kerja yang dihadapi karyawan juga merupakan salah satu alasan untuk mencari alternatif pekerjaan lain. Stres kerja diduga menjadi salah satu faktor terpenting diantara faktor-faktor lainnya yang mempengaruhi turnover karyawan (Hidayati \& Trisnawati, 2016).

Beberapa perusahaan telah memberlakukan Work from Home (WFH) pada pekerjanya dalam langkah pencegahan penularan. Tetapi, sebagian orang tetap harus bekerja penuh di pabrik maupun di kantor. Sebanyak setidaknya 37\% perusahaan masih tetap beroperasi selama masa pandemi ini dan tidak merumahkan karyawannya. Perusahaan yang tetap beroperasi tersebut merupakan perusahaan yang bergerak di sektor industri consumer good, bahan pangan, serta kesehatan. Hal tersebut tentunya menyebabkan pekerja dibidang sektor tersebut sangat rentan terdampak virus covid-19 (Lestari, 2020).

Penelitian lainnya yang dilakukan oleh Hamouche (2020) menyatakan bahwa pada masa pandemi covid-19 dapat dikaitkan dengan banyak stresor yang dapat membuat kesehatan mental pekerja menurun selama pandemi maupun setelah pandemi ini. Menurutnya, stresor selama masa pandemi ini 
diantaranya merupakan ancaman akan risiko penularan, persepsi keselamatan, informasi yang tidak jelas, karantina, dan kondisi kerja.

Penelitian yang dilakukan oleh Iqbal dkk (2014) menyatakan apabila stress kerja dengan turnover intention mempunyai pengaruh yang signifikant. Menurut Rainayee (2013) bahwa stres kerja memiliki pengaruh secara signifikan terhadap turnover intention. Hasil dari penelitian tersebut menunjukan bahwa turnover intention pada karyawan akan meningkat apabila mereka melihat adanya peluang alternatif eksternal dan mengalami stres kerja yang tidak semestinya ditempat kerja mereka.

Dikarenakan kepuasan kerja dan stres kerja merupakan salah satu faktor yang mempengaruhi turnover intention dan banyak penelitian yang menyebutkan bahwa korelasi antara kepuasan kerja dan turnover intention adalah negatif dimana kepuasan kerja tinggi maka turnover intention akan rendah begitu juga dengan sebaliknya. Serta terdapat penelitian yang menyatakan bahwa kepuasan kerja dimasa pandemi lebih rendah daripada sebelum pandemi. Namun, terdapat penelitian yang menyatakan bahwa karyawan memilih bertahan meskipun mereka juga terdampak pengurangan gaji. Dalam Uraian diatas peneliti tertarik untuk meneliti pengaruh kepuasan kerja terhadap turnover intention pada pekerja yang terdampak pengurangan upah masa pandemi.

\section{METODE}

\section{Desain Penelitian}

Penelitian ini menggunakan pendekatan kuantitatif, dimana penelitian ini digunakan agar dapat meneliti sebuah populasi atau sampel tertentu, pengumpulan data ini menggunakan instrumen penelitian analisis data yang bersifat kuantitatif atau statistik dengan tujuan agar dapat menguji hipotesis yang telah ditentukan Suryanto dkk. (2012). Tipe yang digunakan dalam penelitian ini adalah eksplanatori.

\section{Partisipan}

Subjek dalam penelitian ini adalah karyawan yang mengalami pengurangan gaji atau tunjangan pada saat covid. Peneliti menggunakan google form sebagai wadah untuk mengisi kuesioner oleh responden. Hasil dari survei yang di lakukan di google form mendapatkan responden sebanyak 70 orang. Seluruh partisipan telah memberikan informed consent yang telah dilampirkan pada google form.

Partisipan dalam penelitian ini akan menggunakan non probability sampling. Teknik ini digunakan jika tidak memiliki data atau pengetahuan tentang seberapa besar populasi yang harus diteliti. Peneliti menggunakan $G$ power dan diperoleh minimal sample sebanyak 64 partisipan. Untuk menguji hipotesis penelitian penulis menyebar skala kuisioner untuk memperoleh data dari partisipan dan mendapatkan sebanyak 70 partisipan dengan 38 partisipan yang memiliki jenis kelamin laki-laki dan sebanyak 32 partisipan yang memiliki jenis kelamin perempuan.

\section{Pengukuran}

\section{Skala Turnover Intention}

Alat ukur yang digunakan untuk mengukur turnover intention ialah skala yang disusun oleh Mobley dkk. (1978). Alat ukur ini memiliki tiga aspek yaitu berpikir untuk mengundurkan diri, intensi untuk mencari pekerjaan lain, dan intensi untuk keluar. Alat ukur ini menggunakan skala likert dengan lima (5) pilihan jawaban, yaitu sangat setuju, setuju, netral, tidak setuju, dan sangat tidak setuju. Reliabillitas dari turnover intention $(\alpha=0.922)$ dimana alat ukur penelitian ini sangat baik atau reliabel. 


\section{Skala Kepuasan Kerja}

Skala kepuasan kerja dikembangkan oleh Wexley dan Yulk (2003) dengan memuat tiga aspek. Aitem yang diguanakan dalam skala kepuasan kerja berupa aitem-aitem dalam bentuk pernyataan favourable dan unfavourable. Alat ukur ini menggunakan skala likert dengan empat (4) pilihan jawaban, yaitu sangat setuju, setuju, tidak setuju, dan sangat tidak setuju. Reliabilitas dari variabel kepuasan kerja $(\alpha=0.943)$.

\section{Skala Stres Kerja}

Skala yang dibuat oleh Beehr dan Franz (1997) yang dikembangkan oleh Syali (2017) mempunyai 4 indikator yaitu tuntutan peran dan tugas, tuntutan antar pribadi, stuktur organisasi, kepemimpinan organisasi. Aitem yang digunakan dalam skala ini mempunyai total 10 aitem. Alat ukur ini menggunakan skala Likert dengan alternative 5 pilihan jawaban yaitu sangat setuju, setuju, netral, tidak setuju, dan sangat tidak setuju. Reabilitas dari stres kerja merupakan 0.822 dimana reabilitas alat ukur penelitian ini sangat baik atau reliabel.

\section{Analisis Data}

Teknik analisis data yang digunakan dalam penelitian ini adalah Teknik regresi yang bertujuan untuk mengetahui pengaruh antara variabel penelitian (yaitu variabel X terhadap Y). Keseluruhan proses analisis statistik yang digunakan dalam penelitian ini menggunakan SPSS 25.0 untuk windows.

\section{HASIL PENELITIAN}

Subjek dalam penelitian ini adalah karyawan yang mengalami pengurangan gaji atau tunjangan pada saat covid. Dalam pengambilan data, peneliti menggunakan google form sebagai wadah untuk mengisi kuesioner oleh responden. Hasil dari survei yang di lakukan di google form mendapatkan responden sebanyak 70.

Berdasarkan data deskriptif penelitian ini, diketahui variabel turnover intention rata rata sebesar 8,14 dengan standar deviasi sebesar 3,.719 dengan rentang range sebesar 12. Nilai minimal sebesar 3 dan nilai maksimal sebesar 15. Kepuasan kerja mempunyai rata-rata sebesar 98,84 dengan standar deviasi sebesar 20,322 dengan rentang range sebesar 95, nilai minimal sebesar 44 dan maksimal sebesar 139. Stres kerja mepunyai rata-rata sebesar 37,77 dengan standar deviasi sebesar 8,204 dengan rentang rentang sebesar 36, nilai minimal sebesar 13 dan maksimal 49.

Untuk menguji tingkat kepuasan kerja dan stres kerja terhadap turnover intention penulis melakukan Analisa regresi berganda dengan hasil dari $R^{2}$ sebesar 0,063 dimana secara bersamaan variabel independen dapat menjelaskan 6,3\% dari variable dependen. Dalam uji regresi sederhana kepuasan kerja memiliki signifikansi sebesar 0,097 dimana kepuasan kerja tidak berpengaruh terhadap turnoever intention dan stress kerja memiliki signifikansi sebesar 0.661 dimana stress kerja juga tidak berpengaruh significant terhadap turnoever intention.

\section{DISKUSI}

Penelitian ini berbeda dari kebanyakan penelitian sebelumnya dimana hasil dari penelitian mununjukan tidak ada pengaruh yang signifikan antara kepuasan kerja terhadap turnover intention dan stres kerja terhadap turnover intention. Hal ini dapat dikarenakan ada faktor lain yaitu pandemi dimana saat masa pandemi banyak sekali perusahaan yang terdampak, terdapat juga perusahaan yang

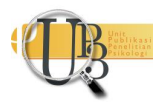


melakukan PHK maupun pengurangan gaji atau tunjangan maupun menyesuaikan jam kerja karyawan agar perusahaan tetap bertahan pada masa pandemi. Adanya pengaruh yang tidak signifikan antara kepuasan kerja dan stres kerja terhadap turnover intention pada karyawan yang mengalami penururunan gaji atau tunjangan juga terjadi karena faktor pandemi yang mengharuskan beberapa perusahaan melakukan beberapa cara untuk mempertahankan bisnis mereka sehingga keadaan ini terjadi hampir diseluruh perusahaan formal karyawan sadar apabila mereka keluar dari pekerjaan yang dijalaninannya untuk mencari pekerjaan lain, keadaan diperusahaan lain kemungkinan tidak akan jauh berbeda dari keadaan perusahan mereka yang sekarang.

Pernyataan peneliti didukung oleh data yang menyebutkan bahwa dampak dari pandemi yang terjadi juga mengharuskan kantor, pabrik, toko ritel sampai industri kecil mengubah pola usahanya. Industri skala besar seperti perusahaan manufaktur otomotif atau garment yang mengandalkan bahan baku produksinya dari rantai pasokan global mengalami gangguan yang cukup berat. Beberapa pabrik yang masih berproduksi pun harus menerapkan aturan jarak antar pekerja dan membagi giliran kerja dengan jumlah pekerja per shift lebih sedikit (Yapanto, 2020). Sehingga selama masa pandemi dampak yang terjadi salah satunya menyebabkan banyak pekerja yang sementara harus dirumahkan atau bahkan terkena PHK, jajaran manajemen perusahaan besar pun banyak yang terkena imbasnya berupa pemotongan gaji atau pengurangan tunjangan (Yapanto, 2020)

Untuk menekan terjadinya turnover intention menurut Suhariadi (2013), terdapat 4 fungsi besar dalam manajemen sumber daya manusia, yaitu pembentukan, pengembangan, motivasi, dan pemeliharaan. Dalam fungsi motivasi ini dilakukan agar individu atau karyawan yang dipilih dan telah dikembangkan kompetensinya tidak segera meninggalkan organisasi atau memiliki intensi untuk turnover. Sangat disayangkan apabila organisasi telah mendapatkan orang yang berkualitas dan telah dikembangkan kompetensinya, secara tiba-tiba ingin mengundurkan diri dan hendak pindah ke organisasi yang lainnya karena dalam proses pengembangan sudah menghabiskan biaya yang tidak sedikit.

Banyak sekali penelitian yang dilakukan sebelum pandemi menujukan bahwa terdapat pengaruh yang signifikan antara kepuasan kerja maupun stres kerja terhadap turnover intention. Contohnya pada penelitian yang dilakukan oleh Yuda dkk (2017) bahwa terdapat pengaruh yang signifikan antara kepuasan kerja dan stres kerja terhadap turnover intention pada karyawan hotel holiday inn express dimana kepuasan kerja berpengaruh negatif dan signifikan sedangkan stres kerja berpengauh secara positif dan signifikan. Hal ini menunjukan bahwa dalam penelitian ini semakin karyawan merasa puas terhadap pekerjaannya maka intensi untuk keluar pekerjaan semakin rendah sedangkan semakin karyawan merasa stress terhadap pekerjaannya makan intensi karyawan untuk keluar dari pekerjaannya akan semakin besar pula. Hasil yang sama diperoleh juga dalam penelitian yang dilakukan oleh Andini dkk (2018) yang menemukan bahwa kepuasan kerja dan stres kerja berpengaruh signifikan terhadap stres kerja pada karyawan PT. Indolakto Faktory Pandaan.

Namun menariknya terdapat beberapa penelitian yang dilakukan pada saat pandemi yang menunjukan hasil yang signifikan antara kepuasan kerja dan stres kerja pada turnover intention seperti penelitian yang dilakukan oleh Rizky dkk. (2020) yang menunjukan bahwa ada beberapa sektor pekerjaan yang tidak terlalu terdampak pandemi seperti pada penelitian ini yang target penelitiannya merupakan PT. FIF group cabang Batu. PT FIF merupakan perusahaan yang bergerak dibidang pembiayaan, dimana perusahaan yang bergerak dibidang ini sangat popular saat pandemi berlangsung, dilansir dari Burhan (2020) bahwa pengajuan pinjaman naik 40\% saat pandemi dikarenakan banyak pekerja yang terdampak pandemi sehingga memilih untuk meminjam uang untuk mencoba membuka bisnis mereka sendiri. 
Dapat disimpulkan bahwa ada beberapa perusahaan yang terdampak negatif oleh pandemi ini namun ada juga yang terdampak positif pada saat masa pandemi, pengaruh kepuasan kerja maupun stres kerja terhadap turnover intention dapat juga dipengaruhi oleh tempat karyawan bekerja, jika tempat karyawan bekerja merupakan sektor perusahaan yang terdampak pandemi secara negatif kemungkinan karyawan tersebut akan memiliki turnover intention yang rendah disebabkan keahlian karyawan tersebut jika digunakan pada sektor perusahaan yang sama keadaannya mungkin tidak akan jauh berbeda.

Saran untuk penelitian selanjutnya agar dapat meninjau pengaruh kepuasan kerja dan stres kerja terhadap turnover intention pada pekerjaan diberbagai sektor sehingga dapat diketahui lebih lanjut apakah sektor perusahaan yang berbeda akan dapat mempengaruhi kepuasan kerja dan stres kerja terhadap turnover intention pada masa pandemi.

\section{SIMPULAN}

Berdasarkan hasil dari penelitian yang dilakukan oleh peneliti kepuasan kerja dan stres kerja berpengaruh 6.3\% terhadap turnover intention. Namun, pengaruhnya tidak signifikan dikarenakan faktor pandemi yang mengharuskan beberapa perusahaan melakukan beberapa cara untuk mempertahankan bisnis mereka sehingga keadaan ini terjadi hampir diseluruh perusahaan formal karyawan sadar apabila mereka keluar dari pekerjaan yang dijalaninannya untuk mencari pekerjaan lain, keadaan diperusahaan lain kemungkinan tidak akan jauh berbeda dari keadaan perusahan mereka yang sekarang.

\section{UCAPAN TERIMAKASIH}

Segala puji bagi Tuhan Yang Maha Esa yang telah memberikan rahmat dan karunia Nya sehingga penulis dapat menyelesaikan naskah ini dengan judul "Pengaruh Kepuasan Kerja dan Stres Kerja Terhadap Turnover intention Pada Karyawan Yang Mengalami Pengurangan Gaji atau Tunjangan Saat Pandemi" ini sebagai salah satu pra syarat untuk mendapatkan gelar Sarjana Psikologi, Universitas Airlangga, Surabaya.

\section{DEKLARASI POTENSI TERJADINYA KONFLIK KEPENTINGAN}

Rizky Nanda Pratama Ibrahim dan Fendy Suhariadi tidak bekerja, menjadi konsultan, memiliki saham, atau menerima dana dari perusahaan atau organisasi manapun yang mungkin akan mengambil untung dari diterbitkannya naskah ini.

\section{PUSTAKA ACUAN}

Andini, R. (2006). Analisis pengaruh kepuasan gaji, kepuasan kerja, komitmen organisasional terhadap turnover intention (Studi kasus pada rumah sakit roemani muhammadiyah semarang) [Master Thesis, Program Pasca Sarjana Universitas Diponegoro]. http://eprints.undip.ac.id/15830/ 
Andini, O. P., Sunuharyo, B. S., \& Utami, H. N. (2018). Pengaruh kepuasan kerja terhadap stres kerja dan turnover intention karyawan (Studi pada karyawan pt indolakto factorypandaan). Jurnal Administrasi Bisnis, 54(1), 1-7.

Burhan, F. A. (2020, April 1). Pengajuan pinjaman naik 40\% saat pandemi, fintech uangteman selektif-Fintech katadata. Co. Id. https://katadata.co.id/desysetyowati/digital/5e9a41f7451a4/pengajuan-pinjaman-naik-40saat-pandemi-fintech-uangteman-selektif

DeMicco, F. J., \& Reid, R. D. (1988). Older workers: A hiring resource for the hospitality industry. Cornell Hotel and Restaurant Administration Quarterly, 29(1), 56-61. https://doi.org/10.1177/001088048802900116

Hamouche, S. (2020). COVID-19 and employees' mental health: Stressors, moderators and agenda for organizational actions. Emerald Open Research, 2, 15. https://doi.org/10.35241/emeraldopenres.13550.1

Handoko, T. H. (1998). Manajemen. Perpustakaan Sekolah Tinggi Ilmu Kepolisian (STIK). http://library.stik-ptik.ac.id

Hidayat, A. S. (2018). Pengaruh kepuasan kerja terhadap komitmen organisasi dan turnover intention. Jurnal Manajemen Dan Pemasaran Jasa, 11(1), 51. https://doi.org/10.25105/jmpj.v11i1.2516

Hidayati, N., \& Trisnawati, D. (2016). Pengaruh kepuasan kerja dan stress kerja terhadap turnover intentions karyawan bag. Marketing pt. Wahana sahabat utama. Eksis: Jurnal Riset Ekonomi dan Bisnis, 11(1). https://doi.org/10.26533/eksis.v11i1.27

Hulin, C. L., Roznowski, M., \& Hachiya, D. (1985). Alternative opportunities and withdrawal decisions: Empirical and theoretical discrepancies and an integration. Psychological Bulletin, 97(2), 233250. https://doi.org/10.1037/0033-2909.97.2.233

Iqbal, S., Ehsan, S., Rizwan, M., \& Noreen, M. (2014). The impact of organizational commitment, job satisfaction, job stress and leadership support on turnover intention in educational institutes. International Journal of Human Resource Studies, 4(2), 181. https://doi.org/10.5296/ijhrs.v4i2.5906

Lestari, A. (2020). Analisis persepsi stres pekerja di masa pandemi covid-19 [Undergraduate Thesis, Universitas Sumatera Utara]. http://repositori.usu.ac.id/handle/123456789/27820

Mathis, R. L., \& Jackson, J. H. (2001). Human Resource Management: Manajemen Sumber Daya Manusia (1st ed.). Salemba empat.

Mobley, W. H., Horner, S. O., \& Hollingsworth, A. T. (1978). An evaluation of precursors of hospital employee turnover. Journal of Applied Psychology, 63(4), 408-414. https://doi.org/10.1037/0021-9010.63.4.408

Pareke, F. J. (2004). Hubungan keadilan dan kepuasan dengan keinginan berpindah: Peran komitmen organisasional sebagai variabel pemediasi. Jurnal Siasat Bisnis, 2(9), 157-178. https://doi.org/10.20885/jsb.vol2.iss9.art3 
Rainayee, R. A. (2013). Employee turnover intentions: Job stress or perceived alternative external opportunities - proquest. International Journal of Information, Business and Management, 5(1), 48-59.

Rizky, K. M., Saroh, S., \& Zunaida, D. (2021). Pengaruh beban kerja, kepuasan kerja, dan stres kerja terhadap turnover intention (Studi kasus pada pt. Fif group cabang batu). JIAGABI (Jurnal Ilmu Administrasi Niaga/Bisnis), 10(1), 110-118.

Rokhmah, B. E., \& Riani, A. L. (2005). Keterkaitan antara komitmen afektif dengan intensi turnover pada karyawan bagian produksi di pt. Usman jaya mekar magelang. Jurnal Ilmiah Teknik Industri, $4(2), 78-85$.

Roza, M. (2020). Perbedaan kepuasan kerja karyawan antar profesi sebelum dan semasa pandemi covid19 di kota palembang [Skripsi, Universitas Muhammadiyah Palembang]. http://repository.umpalembang.ac.id/id/eprint/12787/

Siyamto, Y., \& Saputra, A. (2021). Analisis keuangan keluarga di masa pandemi covid 19. Prosiding Seminar Nasional Ilmu Sosial dan Teknologi (SNISTEK), 3, 162-167.

Suhariadi, F. (2013). Manajemen sumber daya manusia: Dalam pendekatan teoretis- praktis. Airlangga University Press.

Sumarni, Y. (2020). Pandemi covid-19: Tantangan ekonomi dan bisnis. Al-Intaj: Jurnal Ekonomi Dan Perbankan Syariah, 6(2), 46-58. https://doi.org/10.29300/aij.v6i2.3358

Suryanto, Putra, M. G. B. A., Herdiana, I., \& Alfian, I. N. (2012). Pengantar psikologi sosial. Airlangga University Press.

Sutanto, E. M., \& GUNAWAN, C. (2013). Kepuasan kerja, komitmen organisasional dan turnover intentions. Jurnal Mitra Ekonomi Dan Manajemen Bisnis, 4(1), 76-88.

Syali, R. P. (2018). PENGARUH STRES KERJA DAN MOTIVASI KERJA TERHADAP KINERJA KERJA KARYAWAN PT. BINTANG MOTOR JAYA [Skripsi, Universitas Pelita Bangsa]. http://repository.pelitabangsa.ac.id/xmlui/handle/123456789/129

Tillama, P. I., \& Wirawan, I. M. A. (2021). Hubungan beban kerja dan kelelahan kerja dengan turnover intention pada pekerja outsourcing pt $x$ tahun 2020. ARCHIVE OF COMMUNITY HEALTH, 8(1), 155-173. https://doi.org/10.24843/ACH.2021.v08.i01.p11

Yapanto, L. M. (n.d.). Dampak Pandemi Covid-19 Dilihat dari Beberapa Sudut Pandang.

Yuda, I. B. D. P., \& Ardana, I. K. (2017). Pengaruh kepuasan kerja dan stres kerja terhadap turnover intention pada karyawan hotel holiday inn express. E-Jurnal Manajemen, 6(10), 5319-5347. 